\title{
Political media memes as simulacra in media
}

\author{
I.S. Kuznetsov, V.A. Slavina \\ Moscow State Pedagogical University \\ 1 Malaya Pirogovskaya St., Moscow, 119991, Russian Federation
}

The purpose of the article is to analyze the political media memes' structure and to compare them with simulacra according to the theory of Jean Baudrillard. We consider, that media memes have a clear structure via they could spread in social media. This structure also allows media memes to spread in media. Through analysis of political media memes' spreading, generating and evolution as viral units, we could understand post-truth policy. Comparison of political media memes with simulacra could became one more step to better understanding of viral information and post-truth.

Keywords: media meme, social media, media effects, political discourse, simulacra

We often consider media memes as elements of humor, format of culture and units of interpersonal communication. However, they are also a tool of both political discourse and informational policy. After the US presidential elections in 2015-2016 media memes became the new format of political agitation and propaganda. Previously similar tools existed too as the slogans, banners, comics, caricatures etc., but new media and social networks transformed that tool in the format of media meme.

We suppose that media meme is not the only funny images, hashtags and key words. Today's media meme is the format influenced on global informational policy and formed alternative reality in media. It is evident that the objective reality and its representation in media are not the same things, but how great is this difference? Moreover, what is the role of media memes in alternative media reality forming? That are the questions.

First, it is necessary to clarify the common structure of these viral units. According to different works of memetics (Richard Dawkins, Douglas Rushkoff etc.) we suppose that every media meme, as creolized text, viral video or others, has a two-parted structure included:

1. Media meme's shell. This shell is a form of information transmission: video, photo, image, GIF or COUB, draw, etc. The main aim of this part of structure is to appeal users, to attract people who scroll the newsfeed or surf Internet. The shell often has a humoristic nature. It contains external, visual information. According to science analogy "virus = meme", the shell of media meme reminds a capsid of viruses that helps them spread. The shell makes media meme's replication possible: user found a funny image, joke or shocking news sends it to his friends, shares to followers, posts in his profile. This funny image itself is the shell of viral unit.

2. Semantic core of media meme. That is the context of media meme, the main aim of which is to spread ideas, meanings, to influence on public opinion and change minds. 
Semantic core contains internal, semantic information. We suppose that the core is always a complex of meanings, ideas, symbols and means; it is not the only one context. Despite of its humoristic nature, media meme could contain political senses and messages; it could change public opinion being used as a tool of informational policy. According to the analogy between meme and virus, semantic core reminds the DNA under the capsid that infects the cell of victim. Semantic core makes media meme's influence possible. When user laugh on a political meme or joke, he receives a complex of meanings about the meme's subjects: politicians, their programs, ideology, characters, speeches, parties, behaviors etc. This complex could change his minds through the ridicule on such or such subject.

Famous American media analytic Douglas Rushkoff offers an analogy that could help to understand better the media meme's structure. Viral units, "media viruses", as he calls them, remind a Trojan horse. The wooden horse itself is the shell of meme: as Priam, the Trojan ruler, user saws the appealing capsid, a wonderful gift of Greeks and put media meme inside his mind. There Greeks attack Troy - this is the semantic core with its complex of meanings transform user's opinions and persuasions [1]. The main difference between Priam and the user is that Trojan ruler understands how the enemy attacked his city, while our user consider that the changing of his minds is his own volition.

So, various types of thousands of political media memes replicate in social networks, messengers, media and web sites every hour in every country of the world. They have a clear two-parted structure, and we could classify them on different grounds. However, for better understanding of viral formats' replication and their role in contemporary media reality we should analyze their ways of spreading and evolution. There are many versions offered by various researchers, but we consider as quite interesting a theory of French sociologist and philosopher Jean Baudrillard. This theory is called "simulacrum theory", he described it in his famous work "Simulacrums and simulation" [2].

It was Plato, who coined the term "simulacrum". Then French philosophers of the second half of 20th century used the term into their works. First of them was Gilles Deleuze who gave a new definition to Plato's simulacrum in his "Platon et le simulacre" (1969). He wrote that simulacrum is an unreasoned image, a likeness that hide similarity.

Then Baudrillard published his work "Simulacra and simulation" in 1981. He coined a new definition of simulacrum that became universal lately. Baudrillard said that simulacrum is the sign, which has no referent in reality, the representation of something that does not exist. According to his theory, simulacra are copies that depict things that either had no original, or that no longer have an original. Also the simulation is the imitation of the operation of a real-world process or system over time

As Baudrillard says, simulacra are a kind of reflections of real subjects, objects, events and processes of our objective reality that generate, replicate and exist as a part of hyperreality. Baudrillard's simulacra remind Plato's Eidos theory. Simulacra could replace some of political processes, subjects or events, becaming the ones of our objective reality and changing our political culture, media sphere, public opinion and even global policy landscape.

However, the simulacra existed as a science abstraction only until the mass communication processes and Internet development. Some of American researchers 
suppose that new format of information transmission as media meme is a Baudrillard's simulacrum that exists and spreads in media reality as the simulacra do in "hyperreality" of French sociologist.

We suppose that evolution stages of simulacrum and media meme (both of political and humor memeplexes) are similar, as their functioning in media. Baudrillard said that simulacrum has four evolution stages delineated the sign-order:

1. The image/copy as a "good appearance".

2. Theperversionofreality.

3. The masking the absence of a profound reality.

4. Thepuresimulacrum.

Let us see how we can consider media memes as simulacra of virtual reality on the example of one of political media memes "Nambia" that was originated by US president Donald Trump. Certainly, media meme has no absolute compliance with simulacrum. It could have few stages in the same time or have no boundaries between stages because of its fast replication. However, the replication itself could be similar with the one of simulacra - from image or copy of reality to simulation unit, which has no referent object.

1. First stage. It is a faithful image/copy, where we believe, and it may even be correct, that a sign is a "reflection of a profound reality". In his speech during UN General Assembly September 21 in 2017, Trump said about an African country "Nambia". US president could have meant Gambia, Zambia or Namibia. These countries serve as a referent of political media meme.

2. The second stage is perversion of reality, this is where we come to believe the sign to be an unfaithful copy, which "masks and denatures" reality as an "evil appearance it is of the order of maleficence". Here, signs and images do not faithfully reveal reality to us, but can hint at the existence of an obscure reality which the sign itself is incapable of encapsulating. A new simulacrum country "appearances" on world political map. Please note that during this stage "Nambia" exists in the context of the Trump's speech only.

3. The third stage masks the absence of a profound reality, where the sign pretends to be a faithful copy, but it is a copy with no original. Signs and images claim to represent something real, but no representation is taking place and arbitrary images are merely suggested as things which they have no relationship to. During the stage "Nambia" spreads in media and social networks, a strong link with the context fades.

4. The fourth stage is pure simulacrum, in which the simulacrum has no relationship to any reality whatsoever. Here, signs merely reflect other signs and any claim to reality on the part of images or signs is only of the order of other such claims. This is a regime of total equivalency, where cultural products need no longer even pretend to be real in a naive sense, because the experiences of consumers' lives are so predominantly artificial that even claims to reality are expected to be phrased in artificial, "hyperreal" terms. Nambia became simulacrum with own complex of meanings, interpretations and ideas. Meme became meme with its own semantic core, which differs from the referent. Nambia appeals to referents (Zambia, Gambia and Namibia), but is not identical to them, it is the second-order copy. However, Nambia became the symbol of incompetence and 
ignorance of Trump's administration and it is used in American political discourse as newest political cliché.

That is how political media meme transforms from an image, a copy to simulacrum, media text and independent and complete media meme. We suppose that we could add another stage to those formulated by Baudrillard. [3]

5. The fifth stage is a transition from hyperreality to objective reality as a material object. Nambia became a product, a trademark in our reality. They create fake maps of Africa with other countries, which did not exist and incarnate Trump's incompetence. They often refers to other political media meme: MAGAgascar, Kennedia, NIGER [4]. You could also buy a flag of Nambia or "Namibian covfefe" that is also refers to political meme "covfefe".

Both, media meme and its referent appeal to one another, but they are not identical. Nambia, as many others political media memes, is not reflection of objective reality. This is an attempt to materialize the simulacrum, and very successful. Thus, there is a substitution of objective reality by an alternative reality.

Russian philosopher Mikhail Bakhtin [5] and medievalist Dmitry Likhachov, they both supposed that objects of humor culture as jokes, carnivals, anecdotes, funeral customs and ceremonies form an alternative reality, which could replace reality, partially or completely. Dmitry Likhachov called this alternative reality an "anti-world" [6]. We suppose that contemporary humor formats, as media memes, also form an alternative reality in media. This reality is formed by special manipulative techniques, memes, ways of manipulation. It could replace and complement objective reality, which corresponds to the concept of post-truth where lie and truth, political speech and joke, personality and simulacrum are indistinguishable from each other.

(C) Kuznetsov I.S., Slavina V.A., 2018

This work is licensed under a Creative Commons Attribution 4.0 International License

\section{References}

[1] Rushkoff D. Media Virus: Hidden Agendas in Popular Culture. Ballantine Books. N.Y., 1996.

[2] Baudrillard J. Simularca and simulation. Michigan: University of Michigan Press, 1994.

[3] Kuznetsov I.S. Politicheskiy mediamem: ot idei k materialnomu ob'ektu [Political media meme: from idea to material object]. Sovremennye media: protsessy i konteksty: materialy III Mezhdunarodnoy prakticheskoy konferentsii / pod nauch. red. E.A. Ermolina, A.A. Maslovoy. Yaroslavl, 2016.

[4] Baxter J. President of Namibia (aka Nambia) Welcomes Foreigners to "Africa's Best-Kept Secret". South Africa People: URL: https://www.sapeople.com/2017/09/21/president-namibia-akanambia-welcomes-foreigners-africas-best-kept-secret/ (accessed: 16.07.2018).

[5] Bakhtin M. Tvorchestvo Fransua Rable i narodnaya cultura Srednevekovya i Renessansa [Creativity of Francois Rabelais and folk culture of Middle Age and Renaissance]. Moscow: Khudozh. Lit., 1990.

[6] Likhachov D. Smekhovoy mir Drevney Rusi [Laughing World of Ancient Rus]. Leningrad: Nauka, 1976.

Article history:

Received: 1 August 2018

Revised: 5 August 2018

Accepted: 10 August 2018 


\title{
For citation:
}

Kuznetsov I.S., Slavina V.A. (2018). Political media memes as simulacra in media. RUDN Journal of Studies in Literature and Journalism, 23(4), 422-427. DOI 10.22363/2312-9220-2018-23-4422-427

\section{Bio Note:}

Kuznetsov Igor Sergeevich, PhD applicant, Institute of Journalism, Communication and Media, Moscow Pedagogical State University. Contacts: e-mail: kuznetsov0803@mail.ru

Slavina Valentina Alexandrovna, Doctor of Philology, Professor, Institute of Journalism, Communication and Media, Moscow Pedagogical State University. Contacts: e-mail: vslavina@ inbox.ru

\section{Политические медиамемы как симулякры медиапространства}

\author{
И.С. Кузнецов, В.А. Славина \\ Московский педагогический государственный университет \\ Российская Федерация, 119991, Москва, ул. Малая Пироговская, 1
}

\begin{abstract}
Цель данной статьи - анализ структуры политических медиамемов и их сравнение с симулякрами в соответствии с теорией Жана Бодрийяра. Авторы полагают, что медиамемы имеют четкую структуру, при помощи которой они могут распространяться в социальных сетях. С помощью анализа распространения, генерации и эволюции политических медиамемов как вирусных единиц, авторы рассматривают формирование альтернативной реальности и реализацию политики постправды. Сравнение политических медиамемов с симулякрами может стать еще одним шагом к лучшему пониманию вирусной информации и постправды.
\end{abstract}

Ключевые слова: медиамем, социальные медиа, политический дискурс, симулякр, воздействие медиа

\section{Список литературы}

[1] Rushkoff D. Media Virus: Hidden Agendas in Popular Culture // Ballantine Books. N.Y., 1996.

[2] Baudrillard J. Simularca and simulation. Michigan: University of Michigan Press, 1994.

[3] Кузнецов И. Политический медиамем: от идеи к материальному объекту // Современные медиа: процессы и контексты: материалы III Международной практической конференции / под науч. ред. Е.А. Ермолина, А.А. Масловой. Ярославль, 2016.

[4] Baxter J. President of Namibia (aka Nambia) Welcomes Foreigners to "Africa's Best-Kept Secret" // South Africa People. URL: https://www.sapeople.com/2017/09/21/president-namibia-akanambia-welcomes-foreigners-africas-best-kept-secret/ (дата обращения: 16.07.2018).

[5] Бахтин М. Творчество Франсуа Рабле и народная культура Средневековья и Ренессанса. М.: Художественная литература, 1990.

[6] Лихачёв Д. «Смеховой мир» Древней Руси. Ленинград: Наука, 1976.

\section{История статьи:}

Дата поступления в редакцию: 1 августа 2018

Дата принятия к печати: 10 августа 2018 


\section{Для цитирования:}

Kuznetsov I.S., Slavina V.A. Political media memes as simulacra in media (Политические медиамемы как симулякры медиапространства) // Вестник Российского университета дружбы народов. Серия: Литературоведение. Журналистика. 2018. Т. 23. № 4. С. 422-427. DOI 10.22363/2312-9220-2018-23-4-422-427

\section{Сведения об авторах:}

Кузнецов Иван Сергеевич, соискатель ученой степени кандидата наук Института журналистики, коммуникаций и медиаобразования Московского педагогического государственного университета. Контактная информация: e-mail: kuznetsov0803@mail.ru

Славина Валентина Александровна, доктор филологических наук, профессор, заведующая кафедрой журналистики и медиакоммуникаций Института журналистики, коммуникаций и медиаобразования Московского педагогического государственного университета. Контактная информация: e-mail: vslavina@inbox.ru 